\title{
The universities role in the creation of information and consulting technologies of modern agribusiness
}

\author{
Dmitry Eremin ${ }^{1 *}$, and Leonid Skipin ${ }^{2}$ \\ ${ }^{1}$ The State Agrarian University of Northern Zauralye, 625003 Tyumen, Republic Street, 7. Russia, \\ ${ }^{2}$ Tyumen industrial University, 625000, Tyumen, Volodarskogo, 38, Russia.
}

\begin{abstract}
The emergence of many agricultural enterprises of different forms of ownership has led to the need for consulting firms. The proposed solution involves the creation of consulting technology in the field of agribusiness on the basis of specialized universities. The paper presents an analysis of the positive aspects of the use of the scientific potential of the agrarian University in providing farmers with consulting services. The perspective directions of development of consultant technologies are revealed. On the basis of the state agrarian University, the system of rendering services is studied, the most actual directions for an agricultural producer are allocated. It is established that consultations on introduction of results of own research and developmental works on plant growing bring the greatest income- $26 \%$; animal husbandry- $22 \%$; economy and accounting $25.3 \%$ of the total amount of the income. Creation of consulting departments on the basis of agrarian universities through the system analysis providing interrelation between scientists and the agricultural producer is offered. One of the main functions of such departments will be to collect information on the demand of the producer for certain scientific developments and participate in the formation of research strategy at the University.
\end{abstract}

\section{Introduction}

An important role in the modernization of the Russian Federation agriculture belongs to agroconsulting organizations $[1,2]$. With the transition from a planned economy to a market economy and the emergence of farms plurality with different forms of ownership, agricultural producers are faced with a large number of problems that need to be solved independently and in the shortest possible time [3]. During the period of transformation of farms, in many regions of Russia divisions which were responsible for introduction of innovative developments and advanced experience of agricultural science were reduced. It is possible to claim with confidence that the centralized information consulting service in the Russian Federation is absent, and its separate divisions which have degenerated into the commercial enterprises cannot fully render timely and full consulting services to the agricultural producer

\footnotetext{
${ }^{*}$ Corresponding author: soil-tyumen@yandex.ru
} 
[4]. In the South of Tyumen region there are currently almost 600 organizations engaged in the production of agricultural products. The area of arable land on these farms varies from 100 to 35,000 hectares. They are served by about 200 enterprises on processing of production, repair of equipment and the machinery. However, only one of the independent consulting firms operating in the agro-industrial complex was officially registered in 2018. In addition, there are five commercial consulting centers based on the largest suppliers of agrochemicals and equipment.

The appearance of peasant farms and other small agricultural enterprises imposes a certain imprint on the organizational and economic activities. First of all, it should be noted that it is economically unprofitable for small farms to keep economists, accountants, agronomists, livestock specialists and veterinarians of a high level on a permanent basis. This is only possible when cooperatives or other territorial units are established. However, in this case, as the practice of agricultural relations shows, the economic effect of the content of professional specialists is insignificant. In this regard, agro-consulting firms are optimistic associated with the provision of services to agricultural enterprises.

Large farms also face problems of maintaining high-quality professionals on a permanent basis. However, the nature of these problems is different. The specialist should be constantly aware of new products in the market of agrochemicals, modern scientifically based technologies of cultivation of crops or keeping animals.

In this regard, the specialists of agro-consulting enterprises should combine the knowledge of managers, organizers and consultants. The efficiency of such enterprises will depend on the level of competence of each consultant, who should know perfectly the principles of organization of agricultural enterprises, own consulting methods, be able to monitor economic activity and market conditions.

As practice has shown, the existing agro-consulting enterprises rarely meet modern requirements and usually represent a group of 2-5 specialists in a particular branch of agriculture. Most often, certain firms that work in the field of implementation and promotion of some equipment, machinery or agrochemicals provide consulting services. However, as a rule, they advise by advertising their products. In such cases, there can be no question of an objective, independent consultation of farmers.

The purpose of researches. Analyze the existing principles of consulting technologies in agribusiness and identify prospects for providing consulting services to agricultural enterprises of different ownership forms.

\section{Methods}

The research is based on historical and chronological analysis of information and consulting services existing abroad. The experience of research work in the leading agricultural universities in Russia. A detailed analysis of the structure of income from research and development work of the state agrarian University of Northern Zauralye.

\section{Results}

With the transition to a market economy, the provision of consulting services by commercial firms engaged in the production and distribution of any material and technical resources has become widespread in Russia. These are producers and dealers of agrochemicals (plant protection products, fertilizers, adaptogens and stimulants); new agricultural tools and machines; lines for processing of crop and livestock products. There are also commercial firms that develop and sell high - tech products-varieties, breeds of animals, technologies. In the structure of each firm special divisions which duties include work with potential clients 
through carrying out consultations concerning the correct use of the delivered goods or application of technologies are created. Such firms annually spend large sums of money for worthy payment of experts of high level, for their annual training. This has a positive impact on the effectiveness of consulting services. With the development of information technology, such specialists are able to advise farmers on-line in the shortest period, almost without leaving the office [5]. However, this technology of consulting services has significant disadvantages, making commercial firms are not competitive with agricultural universities. Employees of consulting departments should, first of all, ensure the implementation of the interests of their company, which often do not coincide with the interests of producers. During counseling, employees are prohibited from even mentioning the products of their competitors, which makes the consultation ineffective, and sometimes meaningless. Large producers as well as universities conduct demonstration experiments for farmers, but show only their products. Another disadvantage is that advice can be given only in the area in which a firm operates, such as protection of plants. This form of organization of consulting services has been widely spread all over the world.

Independent agro-consulting firms around the world were born in the higher education system based on large agricultural universities. The reason for this was the desire of scientists to obtain a scientific justification for certain processes, the development and testing of mathematical models in real conditions. It is the scientific approach that is the basis for independent consultations, where there is no possibility of allocating a product or technology on a financial basis.

The technology of providing consulting services by agrarian universities has a number of undeniable advantages. The existing teaching staff with experience of working directly with managers and specialists of farms, possessing a powerful scientific Foundation of theoretical justification of modern technologies and organization of production allows to approach systematically the consultation procedure and obtaining the maximum effect from the recommendations. Modern material and technical base and availability of telecommunication facilities allow organizing seminars, exhibitions, and conferences necessary to keep agricultural sector specialists informed of all novelties and innovative developments of national and world science $[6,7,8,9,10]$.

One of the advantages of agrarian universities in the creation of consultant technologies is that they have professional staff in almost all sectors of the agro-industrial complex. powerful material and technical and educational-methodical base of University is used at the organization of consulting services which can be easily expanded due to cooperation of several educational institutions, research institutes and advanced farms [11]. Experience and high qualification of teaching and research staff of faculties, departments and laboratories guarantee high quality of consulting services to producers in almost all areas of agricultural science and practice. It is very important that the commodity producer trusts scientists, because he knows that their opinion regardless of commercial firms or administrative apparatus.

Commercial agro-consulting firms have to hire additionally the same teaching staff of universities to form a comprehensive service. This has a negative impact on the quality of the consultation. The availability of training and experimental farms with modern material and technical base allows universities to create demonstration sites where farmers are given the opportunity to see the achievements of agricultural science, to assess the effectiveness of a technology, the use of agrochemicals, and the possibility of new varieties of crops or farm animalsbreeds. During the demonstrations, agricultural specialists can get qualified answers to questions concerning any field of activity.

Currently, the technology of involvement of senior students and undergraduates in the provision of consulting services is gaining momentum. This has a positive impact on the educational process. The student sees real problems of economy, which he has to solve 
successfully, using the knowledge gained for years of study at University. This method of training is implemented on production practices, which are constantly supervised by experienced mentors. Such technology is also the most interesting for the commodity producer, because it significantly reduces the cost of consultations and makes it possible to see the effectiveness of a potential employee.

Another advantage of universities in the field of consulting technologies in agribusiness is that educational institutions do not pay taxes on value added and profit. This can significantly reduce the cost of services and make the University quite competitive with respect to any commercial organization.

To improve the efficiency on the basis of the University it is possible to create a nonprofit organization engaged in the provision of consulting services using all the scientific and technical potential of the institution and the involvement of other scientific and industrial organizations on a contractual basis.

According to the analysis of the volume of services provided to agricultural producers By the state agrarian University in the period from 2010 to 2015, the most popular were consultations and the introduction of scientific developments in the field of crop production $(26 \%)$ (Fig. 1). The main issues were: optimization of crop rotations and the structure of acreage; recommendations for soil cultivation, fertilization, the use of protective equipment.Also advice on selection of varieties, varietal control, the need for seeds, recommendations on cultivation technology were relevant. With saturation of the market of plant protection products, consulting services on phyto-sanitary control of crops and development of complex technology of crop protection became actual.

Advisory services of the agrarian University in animal husbandry accounted for $22 \%$ of extra-budgetary revenues for the introduction of research and development work. Consultations aimed at the development of diets, the use of feed additives, the organization of herd reproduction and artificial insemination were the most in demand. Services rational use of the herd was in demand with the advent of new technologies of cattle.

The total share of consulting services in accounting and the economy of agriculture was $25.3 \%$ of income. The teaching staff worked in the field of examination of financial and economic condition of agricultural enterprises; participated in the development of optimization of organizational and economic activities of enterprises of various forms of ownership. A separate issue was the organization of crisis management and financial management, as well as the preparation of business plans.

The directions of primary processing $(3.0 \%)$ and ecology $(2.2 \%)$ were in minimal demand. However, the reason for such low activity is strong competition from commercial firms in the field of processing products; in the direction of the environment-the presence of state environmental organizations that carry out total control and provide advice in the field of environmental management. An important function of the scientific agro-consulting is the introduction of innovations into agricultural production, the transfer of modern knowledge to producers [12]. To do this, part of the consulting services can be provided at exhibition and demonstration events, round tables, seminars and conferences.As practice has shown, the most interesting for Tyumen producers were annual events on the basis of the agrarian University and advanced farms called "Field Day". Also, people actively visit exhibitions of agricultural machinery. 


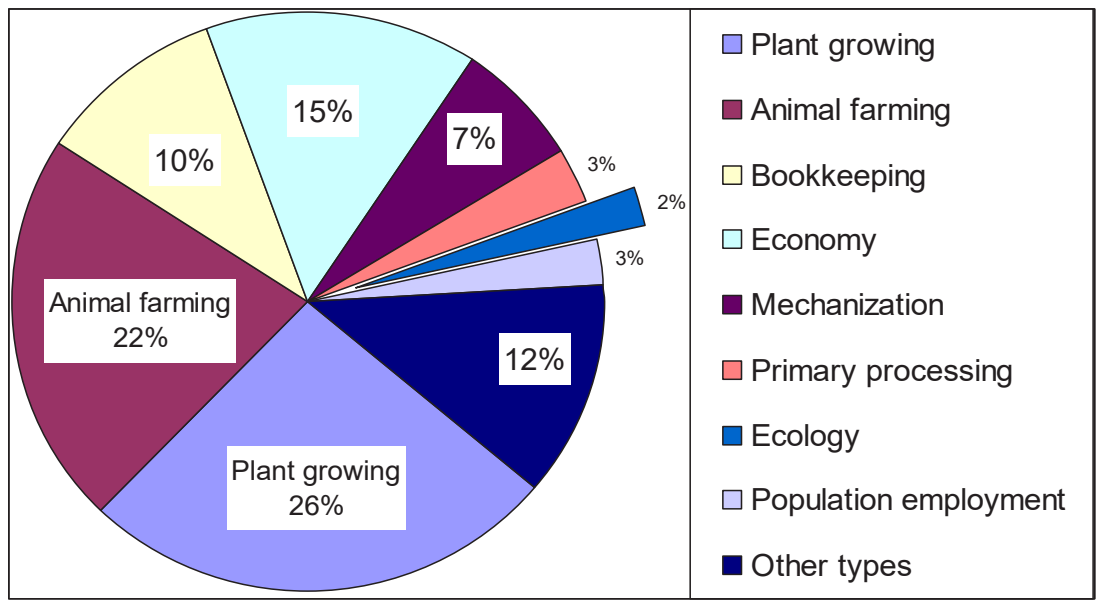

Fig. 1. Services in introduction of research and development works in the State Agrarian University of Northern TRANS-Urals (2010-2015)

The result of universities activity is development, improvement of science-intensive innovative products or technologies, their introduction into production. This gives an advantage to higher education institutions over commercial organizations. The aim of the University's innovation is to create conditions in which scientific research is not interrupted for a long time. This is possible only in the presence of a close relationship between scientists and production. Creation of consulting departments on the basis of the University allows for constant monitoring of demand for high-tech products and technologies. It is also the responsibility of departments to introduce new developments and control at all stages of their development by the producer in the form of consulting services (Fig. 2).

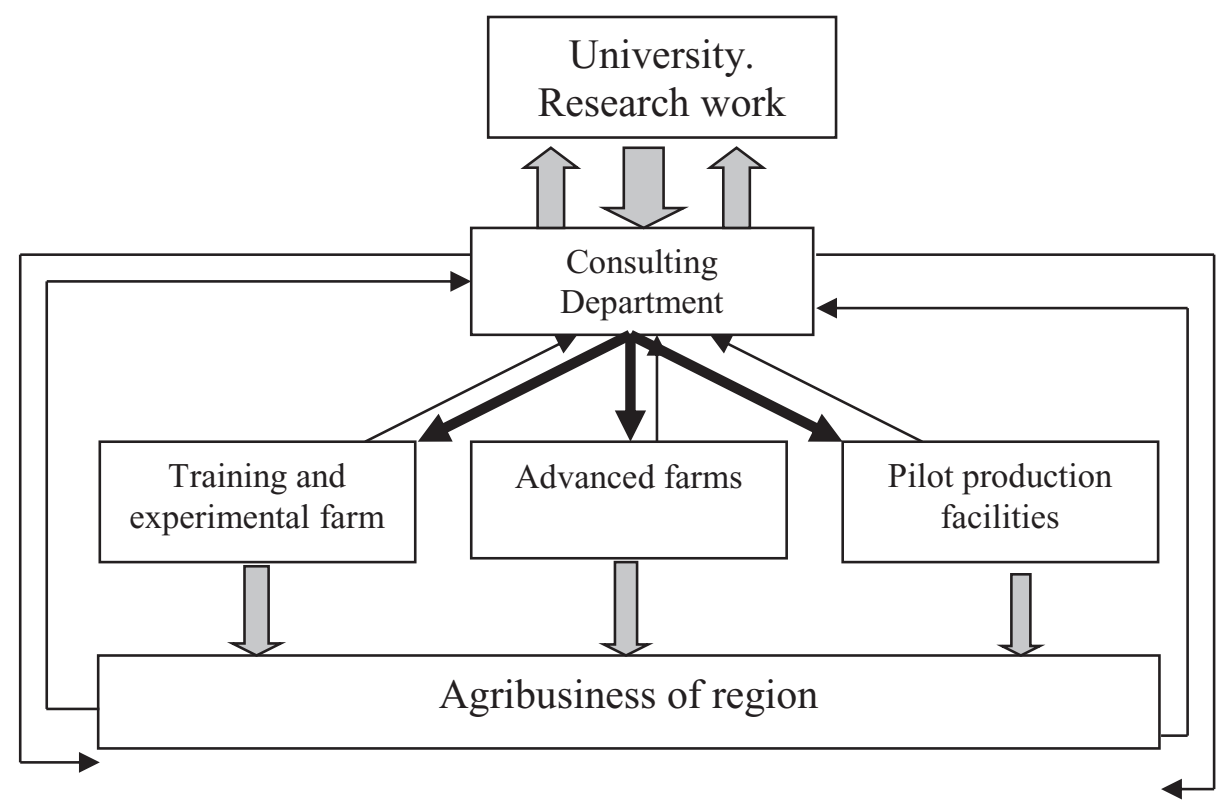

Fig. 2. The role of consulting in the transfer of research and development in the agroindustrial complex. 
The results of research activities of scientists of the University should be transferred to the consulting Department with the necessary documentation and explanations. This enables consultants to fully convey information to specialists, training, experimental, industrial and advanced farms. These enterprises are demonstration sites where farmers can independently assess the effectiveness of development and get the first consultations at the events held on the basis of these farms. It also collects information for debugging technologies or improving the knowledge-intensive product that comes to the University. The term of testing scientific developments on the demonstration site can vary from one year to 3 years. A longer period is impractical, because the high-tech product in the future will not pay off.

After testing in separate farms, scientific developments are replicated and go into mass production. At this stage, the control of implementation and use in agriculture of the region is carried out by the staff of the consulting Department. If their qualification is not enough to solve the problem, a leading scientist responsible for the functionality of this product is called.

Consulting Department, constantly interacting with producers, is designed to provide feedback of production with science. He must constantly monitor the performance of implemented scientific products, see the demand for innovation and collect information about the demand for knowledge-intensive products. Consulting services in the field of innovative developments implementation are in demand by agricultural enterprises all over the world. However, in Russia their importance is much higher, because in the context of reforming agriculture there are numerous changes in financial and credit policy and legislative framework. Numerous farms that have been formed relatively recently cannot fully understand the market situation. The guarantee of survival of farmers in a rapidly changing market economy is a high-quality and scientifically sound system of counseling on all issues.

Consulting services on the basis of the University allow to create a complex of organizational and economic conditions for the effective functioning of agribusiness. A close relationship provides intense use in the production circulation of research results through improved information - consultation and promotional activities.

The main customers of consulting services are agricultural producers of all ownership forms. For commercial consulting firms, economically weak farms are unattractive because they cannot make a profit in the shortest terms [13]. However, for consulting services established on the basis of the University, this is not an obstacle, because the main staff receives income not only in monetary terms, but also in the form of information, which in the future scientists can use to create new knowledge-intensive products and technologies.

Another situation arises in the provision of consulting services to large, economically strong farms. University consulting is faced with serious commercial consulting firms that see a potential buyer in the economy. In this case, the University may prove to be a worthy rival, because, working on the principles of openness of information, it is an independent organization. Implementation of own developments considerably reduces expenses, and their authors working in direct contact with the producer will be the reliable guarantor of fast and effective consultation.

The role of consulting departments at the University is to identify the obvious and implicit demand of the agro-industrial complex of the region. Systematic collection and analysis of such information makes it possible to determine priorities in research, correctly assess the scientific and technical potential of the University and effectively use scientists to solve the problem. The presence of different directions of scientific schools, links between scientists from different universities allow in a short time to respond to the emerging demand for scientific development. Therefore, it is necessary to understand that agricultural science has a powerful scientific potential, which is able to provide a solution to almost any problem, but this requires a clear organization of the scientific and production process.Individual scientists or even small groups cannot work effectively with agricultural producers [14]. Often there 
are questions that may be outside the scope of their scientific competence. Independent attempts to provide advice are usually ineffective and, at least, useless. Therefore, the implementation of agro-consulting requires a coordinating center in the form of a consulting Department.It is from its proper organization will depend on the effectiveness of the relationship between science and production. Only in this case University consulting will be competitive in the market of consulting services.

In recent years, there has been a certain decline in the activity of agricultural science. This happened for various reasons. Government funding has been significantly reduced. There is also a gradual aging of scientific potential - the average age of leading scientists in the agricultural sector is depending on the regions from 65 to 72 years. In many universities, the gap in the scientific continuity of generations has become apparent. The age of scientists, who gradually replace the leading researchers, usually does not exceed $40-45$ years. This is the result of purposeful destruction of science in the nineties of the last century. The founders of scientific schools understand this problem and form a team of young scientists around them. At this stage, consulting departments of universities should actively participate in the formation of a research team that is able to work effectively in market conditions.

In the context of budget cuts, the role of University consulting becomes even more pronounced. The possibility of developing science in the near future will depend on its effective activity. The presence of material interest and the possibility of realizing their potential - is a guarantee of preservation of young scientists in agricultural science. The role of the state in this case is very important.Creation of a deficit of financing and effective stimulation by grant support stimulates the work of research teams, promotes the introduction of research and development work in production. The state can also support universities through the provision of certain benefits to agricultural producers, actively cooperating with agricultural science. This will make it possible to establish close contact and stimulate the financing of science by large enterprises.

\section{Conclusions}

Modernization of the agro-industrial complex through the introduction of modern technology and science-based technologies is one of the most important tasks of agrifood security of the country. Solving this problem will have a positive impact on productivity and profitability of enterprises. Integration of science and agribusiness shows the special role of consulting services provided by specialized universities. The existing practice of conducting research and development work on the introduction of new products and technologies in production has proven the need for the formation of consulting departments at universities. Higher educational institutions have a modern base for practical training of students, teaching staff, who have the opportunity to use expensive scientific equipment of collective centers. Therefore, the provision of Advisory services to agricultural producers will be full and timely. A striking example of the introduction of knowledge-intensive technologies in the agro-industrial sector and the provision of consulting services is the State Agrarian University of Northern Trans-Urals. Thanks to the introduction of its scientific developments, grain crops in Western Siberia for 30 years increased from 1.0-1.5 to 5.0-6.0 t/ha, and milk yield increased by more than 2 times.However, there is a problem that has arisen as a result of the reduction of public funding for research. Long-term research over 5 to 10 years is needed to create a new product or develop innovative technology. In the absence of adequate funding or incentives for agricultural enterprises to implement the results of scientific research on a commercial basis, in the future, the agro-industrial complex of Russia will be forced to buy technology abroad.

For effective provision of consulting services, it is necessary to create specialized departments in agrarian universities, which will be responsible for the connection of science 
with production, evenly distribute the load between the teaching staff, and participate in the organization of research strategy. Entering the market of consulting services of individual scientists will not bring the desired effect, but will only significantly reduce the trust of agribusiness in scientific research and University consulting.

\section{References}

1. D. Cvijanovic, B. Mihailovic, M. Cavlin and G. Cavlin, Sustainability. 7(2), 1099-1115 (2015), doi:10.3390/su7021099

2. M.Busse, W.Schwerdtner, R.Siebert, A.Doernberg, A.Kuntosch, B.König and W.Bokelmann, Agricultural Systems. 138, 55-65 (2015), doi.org/10.1016/j.agsy.2015.05.009

3. A. Shtaltovna, The Journal of Agricultural Education and Extension. 22, 25-41 (2016), doi.org/10.1080/1389224X.2014.997257

4. A.K. Subaeva, A.A. Zamaidinov, International Business Management. 9(7), 1780-1784 (2015)

5. Yu. Weishui, IOP Conf. Ser.: Mater. Sci. Eng. 231, 012030 (2017), doi.org/10.1088/1757-899X/231/1/012030

6. D.I. Eremin, IOP Conference Series: Earth and Environmental Science. 90, 12021 (2017), doi.org/10.1088/1755-1315/90/1/012021

7. A.V. Iglovikov, Procedia Engineering. 165, 800-805 (2016), DOI: 10.1016/j.proeng.2016.11.778

8. D.I. Eremin, Eurasian Soil Science. 49(5), 538-545 (2016), DOI: $10.1134 / \mathrm{S} 1064229316050033$

9. A.V. Lyubimova, G.V. Tobolova, Plant Genetics, Genomics, Bioinformatics and Biotechnology. 39-41 (2015)

10. D.I. Eremin, D.V. Eremina, MATEC Web Conf. 106, 01044 (2017), DOI:10.1051/matecconf/201710601044

11. D.T. Degefie, E. Fleischer, O. Klemm, A.V. Soromotin, O.V. Soromotina, A.V. Tolstikov, N.V. Abramov, Stoch. Env. Res. Risk A. 28, 2161-2173 (2014), DOI: $10.1007 / \mathrm{s} 00477-014-0872-9$

12. C. Eastwood, L. Klerkx, R. Nettle, Journal of Rural Studies. 49, 1-2 (2017). doi.org/10.1016/j.jrurstud.2016.11.008

13. D. Karlan, R. Knight, C. Udry, Journal of Economic Behavior \& Organization. 118, 281302 (2017), doi.org/10.1016/j.jebo.2015.04.005

14. E.A. Vance, The American Statistician. 69, 127-137 (2015), doi.org/10.1080/00031305.2015.1033990 